\title{
Investigating Supply Chain Management Practices in Iranian Manufacturing Organizations
}

\author{
Changiz Valmohammadi \\ Islamic Azad University-South Tehran Branch \\ Department of Industrial Management \\ Faculty of Management and Accounting \\ Shariati Ave. Tehran - Iran \\ E-mail: ch_valmohamadi@azad.ac.ir
}

\begin{abstract}
The aim of this article is threefold, firstly to investigate the extent of supply chain management (SCM) practices implementation in Iranian manufacturing organizations, secondly, given contextual factors of the country to identify benefits and barriers of SCM implementation and thirdly, to survey if there is any relationship between SCM practices and organizational performance of Iranian manufacturing organizations, mainly based on a descriptive analysis. Based on the review of literature main practices and also benefits and barriers of SCM implementation was identified. A self administered questionnaire was designed and distributed among 127 logistics and manufacturing managers of Iranian manufacturing organizations, of which 97 complete questionnaires returned, yielding a response rate of about 76 percent. Through descriptive statistical analysis the extent of SCM practices, main benefits and barriers in the surveyed organizations and their ranking orders were determined. Results revealed that holding safety stock is the most implemented practice of SCM. Also, increased customer satisfaction and inadequate information sharing in the chain were ranked as the major benefit and barrier of SCM implementation respectively. The result of chi-square test showed that the implementation of SCM practices is positively and significantly related to organizational performance of Iranian manufacturing companies.
\end{abstract}

Keywords: Supply Chain Management, exploratory analysis, organizational performance, benefits and barriers, Iran

\section{INTRODUCTION}

Globalization and intensive world-wide competition along with the technological advancements create an entirely new business environment for the manufacturing organizations (Koh, et al. 2007). Organizations today operate in an uncertain and competitive business environment. One way to address these challenges is to implement supply chain management (SCM) (Chong et al., 2011). Thongrattana and Perera (2010) argue that uncertainty has caused many companies across many industries to engage in an on-going process of adoption of SCM.

The term SCM was first used in the 1980s and as such is a relatively new discipline within management theory with tools and concepts still being developed. The subject is multidisciplinary which has its origins in a number of fields including purchasing, logistics and operations. Given its multidisciplinary nature there is the requirement for crossboundary management (Lummus \& Vokurka, 1999).
The strategic supply chain continues to be adopted by organizations as the medium for creating and sustaining a competitive advantage. Such a displacement is understandable considering the potential benefits of successful supply chain management (SCM). These benefits include inventory reduction, improved delivery service, and shorter product development cycles (Fawcett et al., 2008). Firms try to develop value-added processes that deliver innovative, high-quality, low-cost products on time, with shorter cycle times and greater responsiveness than ever before. One of the ways of realizing this goal is to collaborate with supply chain partners (Ramesh et al., 2010).

Fawcett et al. (2008) by literature argue that despite these enticing benefits, organizations who partner in strategic supply chains continue to encounter barriers. They continue," these barriers exist at multiple levels of organization: the organizational, intra-organizational, interorganizational levels. For example, strategic supply chains may encounter performance "glitches" or the inability to meet customer demand from such things as quality and production problems, employee apprehension to yield up control, and poor collaborative planning. These glitches can be quite costly in terms of higher inventory and lower sales growth".

The desire of Iranian manufacturing to SCM practices is heavily related to the rising pressure from fierce completion in the marketplace of the country, particularly after deregulation and privatization of most industries by the government which has been starting since about 20 years ago. So, most manufacturing industries like petrochemical and automotive ones look at SCM from a strategic angle in order to improve their competitiveness which could increase market share both at national and international levels. As Spens \& Wisner (2009) note the practice of SCM is receiving a growing amount of interest from practitioners as well as academia, and many efforts to explain and describe the essence of SCM exist in the literature. On the other hand due to the dearth of research regarding SCM practices, benefits and barriers of implementing it in the context of Iran, this study attempts to survey these issues.

\section{LITERATURE BACKGROUND}

Over the past 25 years, SCM has been evolving as concept and gradually managers have accepted that their firm is just one entity in the chain of firms whose purpose is to satisfy the customer. In order to develop such thinking, a lot of support is provided by researchers from academia, industry 
and consultants (Soni \& Kodali, 2011). But as Stock \& Boyer (2009) state a high level of confusion has occurred amongst supply chain scholars during the past decades by the several SCM definitions that have been proposed in the literature.

The supply chain concept is theorized from the formation of a value chain network consisting of individual functional entities committed to providing resources and information to achieve the objectives of efficient management of suppliers as well as the flow of parts. SCM includes a set of approaches and practices to effectively integrate suppliers, manufacturers, distributors and customers for improving the long-term performance of the individual firms and the supply chain as a whole in a cohesive and high-performing business model. As defined by the Council of Supply Chain Management Professionals (CSCMP), SCM encompasses the planning and management of all activities involved in sourcing and procurement, conversion and all logistics management activities as well as coordination and collaboration with channel partners (Koh et al., 2007). SCM practices are defined as the set of activities undertaken by an organization to promote effective management of its supply chain; as the approaches applied in integration, managing and coordination of supply, demand and relationships in order to satisfy clients in effective way; as tangible activities/technologies that have a relevant role in the collaboration of a focal firm with its suppliers and/or clients; and as the approach to involve suppliers in decision making, encouraging information, sharing and looking for new ways to integrate upstream activities.

As a consequence, it involves developing customer contacts by customer feedback to integrate the downstream activities and delivering orders directly to customers. In this sense, studying SCM practices supports the view theory regarding SCM (Jabbour et al., 2011). Owing to the evolutionary nature and complexity of SCM, many SCM research studies have focused only on the upstream or downstream aspects of SCM. To address the limitations of the existing literature, $\mathrm{Li}$ came up with a unifying SCM practices framework that includes both the upstream and downstream sides of the supply chain (Chong et al., 2011). Christopher (1998) defined supply chain as a network of organizations that are involved, through upstream and downstream linkages, in the different processes and activities that produce value in the form of products and services in the hands of the ultimate consumer. Alvarado \& Kotzab define SCM practices in terms of reducing duplication effects by focusing on core competencies, and use of inter-organizational standards such as activity-based costing or EDI, and eliminating unnecessary inventory levels by "postponing customizations towards the end of the supply chain" (Chong et al., 2011).

Whichever definition is applied, in today's dynamic business environments cost effective SCM is a matter of survival as purchased goods and services account for up to 80 percent of sales revenue. Building on the idea of SCM as a strategic shift in a company's governing principles; SCM must be seen as a professional practice and one which is at the heart of an organisation's corporate strategy. The importance of effective SCM can also be seen in an organisation's ability to gain a competitive advantage (Meehan \& Muir, 2008). Based on the literature above, SCM practices are portrayed from different perspectives with a common aim of improving organizational performance (Chong et al., 2011).

Also, Scholars such as (Hsu et al., 2010; Ramesh et al., 2010; Chong et al., 2011; Fawcett et al., 2008; Koh et al., 2007) have studied and identified various practices for successful and effective implementation of SCM and also benefits and barriers of SCM implementation. Companies can expect to achieve many different benefits through effective implementation of supply chain practices as mentioned before in the paper. On the other hand review of literature (Chong et al., 2011; Petrovic-Lazarevic et al., 2007; Li et al. 2006; Koh et al., 2007; de Souza Miguel \& Ledur Brito, 2011; Spens \& Wisner, 2009) indicates that there is positive and significant relationship between SCM and organizational performance. Where the mentioned studies found positive relationship between SCM and performance, others were not conclusive. For instance, scholars have found conflicting results in their study such as weak support for the impact of cooperation on flexibility and delivery and information sharing on overall operational performance (Miguel \& Ledur Brito, 2011).

The aim of this study is threefold; first to investigate the extent to which Iranian organizations implement SCM practices. Second, given contextual factors of the country what are their main benefits and barriers of SCM implementation for Iranian organizations? And finally it investigates if there is a relationship between the implementation of SCM practices and organizational success of Iranian manufacturing organizations. Therefore for the purpose of this study the following research questions are raised:

RQ 1: To what extent do Iranian manufacturing organizations implement supply chain practices?

RQ 2: What are the main drivers and barriers for implementing supply chain practices in Iranian manufacturing organizations?

RQ 3: What is the relationship between supply chain practices and organizational performance of Iranian manufacturing organizations?

\section{RESEARCH METHODOLOGY}

To address the research questions, an exploratory survey was carried out in a representative sample of 127 manufacturing organizations from various industry sectors in Iran. The data collection took about two and half months and was collected from December 2011 to Febuary 2012. The questionnaire used to collect the data was pretested twice based on the method employed by Battor \& Battor (2010). First, a pretest involving five academics and three executives was conducted to assess the face and content validity of the measurement items. Consequently, a small number of modifications to the questionnaire were made. Second, a pilot study was done to confirm the appropriateness of the questionnaire.

The questionnaire was distributed via email and postal mail for organizations requesting them to response within one month. After the end of the deadline as Baruch \& Holtom (2008) argue in order to increase the response rate 
via the aforementioned communications channels a reminder letter was sent to those firms who had not responded, asking them to response the questionnaire and send it back within one week. Building on key informant approach (Silk\& Kalwani, 1982) the pool of potential respondents was restricted to the manufacturing and logistics managers of the respective organizations. A data base on manufacturing organizations provided by ministry of industry served as the basis for the survey. In total 97 statistically useful questionnaire were returned, resulting in a response rate of about 76 percent. Data analysis entailed the use of both descriptive methods to provide exploratory insights into the nature of SCM practices in Iranian manufacturing organizations and the use of statistical analysis. Being exploratory, the survey was kept relatively short (Ahlstom \& Westbrook, 1999). Most items asked the respondents to rank issues surrounding their SCM endeavour. Issues included extent of various SCM practices usage, and benefits \&difficulties that were experienced with the SCM endeavour.

The items of the questionnaire the respondents could choose from, were based on the existing literature (Hsu et al., 2009; Koh et al., 2007; Wong et al., 2005; Chong et al., 2011; Ramesh et al., 2010; Fawcett et al., 2008; Meehan and Muir, 2008). Although the use of Likert scales would have permitted more rigorous analysis, we chose to stay with ranking scales. Since the survey was exploratory, ranking scales were preferred over the development of more precise scales. For the same reason, rigour in analysis was not seen as an important criterion at this stage (Ahlstom \& Westbrook, 1999). Ranking scales generate only ordinal data, which are not analysable by ordinary parametric statistics. The manner in which the data are summarised is to some extent left to the discretion of the researcher, since no standard methods exist (Ahlstom \& Westbrook, 1999).

The main part of the organizations (67\%): came from one of the following industries: automotive (24\%), textile (16\%), food (14\%), and chemical/pharmaceutical (13\%) and the remaining belonged to plastic $(10 \%)$, electronics and ICT $(9 \%)$, mechanical $(8 \%)$ and others $(7 \%)$. Also, majority of companies had between 500 and 1200 employees (69 percent), 18 percent of the companies responded had between 250 and 450 employees and 13 percent of the companies responded had less than 100 employees. The surveyed organizations consisted of organizations that had been involved in implementing SCM practices from four to over ten years. Organizations that did not practice SCM were not considered.

Regarding the SCM practices used by study's sample, respondents were asked to mark the practice or practices from the designed questionnaire mentioned above, with the option to fill in other practices. The list and corresponding responses are shown in table 1.

Table 1. SCM practices

\begin{tabular}{|ll|}
\hline$\bullet$ & Increase suppliers' just in time capabilities \\
\hline$\bullet$ & $\begin{array}{l}\text { Improving the integration of activities(internal } \\
\text { operation) }\end{array}$ \\
\hline$\bullet$ & Product differentiation \\
\hline$\bullet$ & Lead time management \\
\hline$\bullet$ & Communicating future strategic needs \\
\hline
\end{tabular}

\begin{tabular}{|ll|}
\hline$\bullet$ & Geographical proximity of suppliers \\
\hline$\bullet$ & Outsourcing \\
\hline$\bullet$ & Strategic planning \\
\hline$\bullet$ & $\begin{array}{l}\text { Information technology (IT)such as the EDI, ERP, e- } \\
\text { procurement and CRM }\end{array}$ \\
\hline$\bullet$ & Holding safety stock \\
\hline$\bullet$ & Strategic supplier partnership \\
\hline - & Supply chain performance \\
\hline$\bullet$ & Information sharing and coordination \\
\hline$\bullet$ & Postponement and customization \\
\hline$\bullet$ & Supply chain benchmarking \\
\hline$\bullet$ & Subcontracting \\
\hline
\end{tabular}

\section{RESULTS}

Descriptive analysis shows more than 67 percent of the organizations under study have classified all of SCM practices mentioned above "important" or "very important". About 90 percent use holding safety stock as the main practice of SCM which it is not surprising, since due to so much fluctuations and economic instability and in order to overcome this situation, Iranian companies tend to increase range of stock (Valmohammadi, 2011a). The least rated and indeed used practices are IT technologies and supply chain benchmarking. this finding is consistent with the result of the study of Koh et al. (2007) where they found that eprocurement practice is not used widely in Turkish SMEs .The most important reason which could be attributed to the low utilization of IT technologies in the Iranian organizations is the poor ICT infrastructure and the lack of adequate skilled people and scarcity of financial resources which contrary is overwhelmingly utilized in the developed countries' organizations. Also this finding is in line with the result of the study of Valmohammadi (2012) where he found poor IT infrastructure and the lack of full e-government realization is the main obstacle in teleworking implementation in Iranian organizations.

Regarding the second less employed practice among the sample organizations, given the difficulties and unwillingness of organizations to cooperate and share their knowledge and experiences with their partners, both at the national and international levels, the low rank of supply chain benchmarking practice is not surprising. The ranking of SCM implementation based the frequency cited by respondents are found in table 2.

Table 2. Ranking of SCM practices implementation according to respondents

\begin{tabular}{|c|l|c|}
\hline Rank & \multicolumn{1}{|c|}{ Practices } & $\%$ \\
\hline 1 & Holding safety stock & 67 \\
\hline 2 & Subcontracting & 63 \\
\hline 3 & Strategic planning & 60 \\
\hline 4 & Lead time management & 59 \\
\hline 5 & Geographical proximity of suppliers & 56 \\
\hline 6 & Outsourcing & 50 \\
\hline 7 & Communicating future strategic needs & 48 \\
\hline
\end{tabular}




\begin{tabular}{|c|l|c|}
\hline Rank & \multicolumn{1}{|c|}{ Practices } & $\%$ \\
\hline 8 & Product differentiation & 47 \\
\hline 9 & $\begin{array}{l}\text { Improving the integration of activities } \\
\text { (internal operation) }\end{array}$ & 45 \\
\hline 10 & $\begin{array}{l}\text { Increase suppliers' just in time } \\
\text { capabilities }\end{array}$ & 43 \\
\hline 11 & Postponement and customization & 42 \\
\hline 12 & Strategic supplier partnership & 41 \\
\hline 13 & Supply chain performance & 40 \\
\hline 14 & Information sharing and coordination & 39 \\
\hline 15 & Supply chain benchmarking & 37 \\
\hline 16 & $\begin{array}{l}\text { Information technology (IT)such as the } \\
\text { EDI, ERP, e-procurement and CRM }\end{array}$ & 36 \\
\hline
\end{tabular}

\section{BENEFITS AND BARRIERS FOR IMPLEMENTING SCM}

Before investing money, time, and other resources into difficult implementations, most managers want to know if the results are worth the effort. Identifying and quantifying the expected benefits is a critical part of any cost/benefit analysis (Fawcett et al., 2008). So, in this research benefits and barriers of SCM practices based on the extant literature was studied and determined. This could help Iranian manufacturing organizations to know what the most important benefits are, as a result of SCM implementation. And they will also be able to apply necessary measures to remove the barriers and use it for their cost /benefit analysis.

Asked on their subjective evaluation of SCM practices, 74 percent of the respondents ranked increased customer satisfaction and cost reduction across the chain as the first and second most important benefits expected and realized of SCM implementation. This is probably because organizations feel customers increasingly demand diverse products. Thus, in order to remain competitive in the market, through implementation of SCM practices such as postponement and customization strategy, geographical proximity of suppliers, and JIT supply, they can lower costs while meeting diverse needs of their customers. Ultimately, these practices could lead to increased customer satisfaction. This result is congruent with the findings of the survey done by Fawcett et al., (2008) where they found that satisfying customer needs is the primary benefit cited by respondents. The other benefits based on the frequency cited by respondents are shown in table 3.

Table 3. Ranking of SCM practices implementation according to respondents

\begin{tabular}{|c|l|c|}
\hline Rank & \multicolumn{1}{|c|}{ Practices } & $\%$ \\
\hline 1 & Increased customer satisfaction & 75 \\
\hline 2 & Cost reduction across the chain & 73 \\
\hline 3 & Increased revenue & 67 \\
\hline 4 & Market penetration & 66 \\
\hline 5 & Reduced purchasing costs & 64 \\
\hline
\end{tabular}

\begin{tabular}{|c|c|c|}
\hline Rank & Practices & $\%$ \\
\hline 6 & On-time delivery & 62 \\
\hline 7 & Increased inventory turnover & 60 \\
\hline 8 & Decreased order cycle times & 58 \\
\hline 9 & Reduction in risk & 57 \\
\hline 10 & Shorter order fulfillment lead times & 55 \\
\hline 11 & Greater product availability & 54 \\
\hline 12 & $\begin{array}{l}\text { Reduction in the duplication of inter- } \\
\text { organizational processes }\end{array}$ & 51 \\
\hline 13 & $\begin{array}{l}\text { Increased customer/market } \\
\text { responsiveness }\end{array}$ & 50 \\
\hline 14 & Capital utilization & 48 \\
\hline 15 & Decreased product time to market & 47 \\
\hline 16 & Logistics cost reduction & 45 \\
\hline 17 & Transportation costs & 44 \\
\hline 18 & Handle unexpected challenges & 41 \\
\hline 19 & Overall product quality & 39 \\
\hline 20 & $\begin{array}{l}\text { Reduction in product development } \\
\text { cycle time processes }\end{array}$ & 38 \\
\hline
\end{tabular}

To assess the barriers and difficulties encountered by the surveyed organizations regarding SCM implementation, respondents were asked to rank a number of outcomes mentioned in the questionnaire. In table 4 the barriers and difficulties associated with SCM implementation have been ranked, which is based on the frequency cited by respondents on each of them.

Table 4. Barriers of implementing SCM in Iranian manufacturing organizations

\begin{tabular}{|c|l|c|}
\hline Rank & \multicolumn{1}{|c|}{ Practices } & $\%$ \\
\hline 1 & Inadequate information sharing & 72 \\
\hline 2 & Poor understanding of SCM & 70 \\
\hline 3 & Information systems and technology & 68 \\
\hline 4 & Deficiencies (IS /IT) & 67 \\
\hline 5 & Top management commitment & 65 \\
\hline 6 & Lack of vision of SCM & 63 \\
\hline 7 & Internal and external turf wars & 61 \\
\hline 8 & Poor SCM planning & 60 \\
\hline
\end{tabular}




\begin{tabular}{|c|l|c|}
\hline Rank & \multicolumn{1}{|c|}{ Practices } & $\%$ \\
\hline 9 & Organizational culture \& people training & 59 \\
\hline 10 & Lack of channel trust & 58 \\
\hline 11 & Lack of SC measurement & 56 \\
\hline 12 & Lack of alliances guidelines & 53 \\
\hline 13 & Reduction in product quality & 51 \\
\hline 14 & Lack of collaborative strategic planning & 50 \\
\hline 15 & Unwillingness to share risk and reward & 49 \\
\hline 16 & $\begin{array}{l}\text { Disparity in technological capability } \\
\text { among partners }\end{array}$ & 47 \\
\hline 17 & Measuring customer demand & 44 \\
\hline
\end{tabular}

As can be seen in table 4 the first ranked factor is" inadequate information sharing" and the second ranked factor is "poor understanding of SCM among Iranian organizations" .Regarding the main barrier it is in line with the finding of Manzouri et al. (2011) where their survey revealed both Iranian and Malaysian companies suffer from the lack of information across the chain as a major difficulty in implementing SCM. Also, on the second major barrier this is in line with the finding of the study of Valmohammadi (2011b) on Iranian manufacturing SMEs where he points out that most Iranian organizations have no effective and strong mutual relationship with their suppliers. Also, he argues that most Iranian organizations particularly small and medium sizes enterprises (SMEs) employ traditional methods and approaches on material requirements planning (MRP) and are unfamiliar with the new methods and techniques of SCM.

Organizational performance is an indicator which measures how well an organization accomplishes its objectives (Ho, 2008). Based on the discussion of Baruch \& Ramalho (2006) that argue an author's choice for a given measure might depend on the measures previously chosen, two measures used in the research of Koh et al., (2007) i.e. cost saving and reduced inventory level were selected to address RQ 3. Owing to the fact these performance measures have been used in the context of a developing country (i.e. Turkey) like Iran, thus the researcher decided to use the same measures in this study. Table 5 shows mean and standard deviation of the measures.

Table 5. Calculation of mean and standard deviation of organizational performance

\begin{tabular}{|llc|}
\hline Measures & Mean & S.D \\
\hline Cost saving & 4.1 & 0.72 \\
Reduced inventory & 3.9 & 0.81 \\
\hline
\end{tabular}

The researcher examined if there is a statistically significant relationship between the implementation of SCM practices and organizational performance. The interpretation of subjective, relative performance data is easier and more accurate across diverse context factors, such as across industries, and several studies illustrate the high correlation between subjective and objective performance indicators (Arendt and Brettel, 2010). Respondents were requested to indicate based on their view the extent to which they think two measures of cost saving and reduction in inventory level are directly related to SCM practices in their organizations during the past 3 years. Both questions were measured using Likert scales, ranging from strongly agree (5) to strongly disagree (1). For both performance indicators, statistically significant difference could be identified between those companies which implement most of SCM practices and those organizations which apply just some of SCM practices, using a chi-square test (see table 6).

Table 6. $\mathrm{Chi}^{2}$-square for Group Differences

\begin{tabular}{|c|c|c|c|c|}
\hline $\begin{array}{c}\text { Performance } \\
\text { measure }\end{array}$ & Method & Value & df & $\begin{array}{l}\text { Asympt. } \\
\text { Sig. }\end{array}$ \\
\hline \multirow[t]{2}{*}{ Cost saving } & $\begin{array}{l}\text { Chi }{ }^{2} \\
\text { (Pearson) }\end{array}$ & 1.42 & 2 & 0.0501 \\
\hline & $\begin{array}{l}\text { Likelihood } \\
\text { Ratio }\end{array}$ & 1.17 & 2 & 0.0512 \\
\hline \multirow{2}{*}{$\begin{array}{l}\text { Reduction in } \\
\text { inventory } \\
\text { level }\end{array}$} & $\begin{array}{l}\text { Chi }^{2} \\
\text { (Pearson) }\end{array}$ & 1.573 & 2 & 0.0514 \\
\hline & $\begin{array}{l}\text { Likelihood } \\
\text { Ratio }\end{array}$ & 1.616 & 2 & 0.0521 \\
\hline
\end{tabular}

Accordingly, the present study can confirm that the application of SCM practices is significantly related to organizational performance in the Iranian business context. This result is in accordance with the findings of Miguel and Ledur Brito (2011) where they found that SCM practices have a positive impact on the operational performance of Brazilian companies. Also, it is consistent with the results of Spens and Wisner (2009) study which in their cross national survey on 155 Finish and U.S. organizations they found positive impact of SCM practices on organizational performance in both countries albeit at different extent. Also, one possible explanation might be that other savings in inventory (e.g. reductions in inventory-in-transit) are more than offsetting the high safety stocks.

\section{CONCLUSION AND DISCUSSION}

This article investigated the extent to which SCM practices in Iranian manufacturing organizations are employed, mainly based on a descriptive analysis. The results of the empirical investigation demonstrate that most SCM practices are relatively highly implemented in Iranian manufacturing companies. The most implemented practice of SCM is "holding safety stock" and the least employed practice is "IT related technologies such as EDI, e-procurement and CRM implementation". Regarding benefits and barriers related to SCM implementation, descriptive analysis demonstrates they believe increase of customer satisfaction and cost reduction across the chain are the main benefits that motivate organizations to pursue SCM practices. Also, the surveyed companies ranked "inadequate information sharing across 
the chain " and "poor understanding of SCM " as the main barriers towards successful implementation of SCM.

This result requires paying much more attention by the related policy makers of the country. As the barriers are relatively general subject, it is required to increase training among various levels of employees and managers in Iranian organizations to become more familiar with the concepts, practices and IT technologies such as" EDI, e-procurement and CRM systems. As Zailani et al. (2008) argue the sharing of information among firms in a supply chain reflects the importance of SCM. Also, development and improvement of IT infrastructures should be given high priority in the country. Various SCM authors and scholars have emphasized on the important role of IT in the coordination of supply chain (Chatzoudes \& Chatzoglou, 2011).

The relationship between SCM practices and organizational performance was another subject which was studied and the result of chi-square test revealed that there is a positive and significant relationship between SCM practices and organizational performance measures, i.e. "cost saving" and "reduction in inventory level" in Iranian manufacturing context. Almost 90 percent of the surveyed companies regard SCM practices "important" or "very important". The surveyed organization have found out the importance and the role of SCM practices in lowering costs while meeting diverse needs of their customers in this today's changing and challenging economic times, which hopefully will lead to increased customer satisfaction.

Acknowledgement - The author wishes to thank the anonymous reviewer of OSCM Journal for his/her helpful comments which improved the early draft of this paper.

\section{REFERENCES}

Ahlstom, P., and Westbrook, R. (1999). Implications of mass customization for operations management, An exploratory survey, International Journal of Operations \& Production Management, 19 (3), pp. 262-274.

Arendt, S., and Brettel, M. (2010). Understanding the Influence of Corporate Social Responsibility on Corporate Identity, Image, and Firm Performance, Management Decision, 48(10), pp.1469-1492.

Baruch, Y., and Ramalho, N. (2006). Communalities and Distinctions in the Measurement of Organizational Performance and Effectiveness across For-Profit and Nonprofit Sectors, Nonprofit and Voluntary Sector Quarterly, 35 (1), pp.39-65.

Baruch, Y., and Holtom, B. C. (2008). Survey response rate levels and trends in organizational research, Human Relations, 61(8), pp.1139-1160.

Battor, M., and Battor, M. (2010). The impact of customer relationship management capability on innovation and performance advantages: testing a mediated model, Journal of Marketing Management, 26(9-10), pp.842857.

Chatzoudes, D., and Chatzoglou, P. (2011). The Impact of 360 Supply Chain Integration on Operational and Business Performance, Operations and Supply Chain Management: An International Journal, 4(2/3), pp. 145-156.
Chong, A. Y. L., Chan, F. T. S., Ooi, K. B., and Sim, J. J. (2011). Can Malaysian firms improve organizational/innovation performance via SCM? Industrial Management \& Data Systems, 111(3), pp. 410-431.

Christopher, M. (1998). Logistics and Supply Chain Management, Pitman, London.

Fawcett, S., Magnan, G. M., and McCarter, M. W. (2008). Benefits, barriers, and bridges to effective supply chain management, Supply Chain Management: An International Journal, 13(1), pp. 35-48.

Ho, L.A. (2008). What affects organizational performance? The linking of learning and knowledge management, Industrial Management \& Data Systems, 108 (9), pp. $1234-1254$.

Hsu, C. C., Tan, K. C., Kannan, V. R. and Leong, K. G. (2009). Supply chain management practices as a mediator of the relationship between operations capability and firm performance, International Journal of Production Research, 47 (3), pp. 835-55.

Jabbour, A. B. L. d. S., Filho, A.G. M.Viana, A. B. N. and Jabbour, Ch. J. Ch. (2011). Measuring supply chain management practices, Measuring Business Excellence, 15(2), pp. 18-31.

Koh, S. C. L., Demirbag, M., Bayaraktar, E., Tataglu, E., and Zauim, S. (2007). The impact of supply chain management practices on performance of SMEs, Industrial Management \& Data Systems, 107 (1), pp. 103-124.

Li, S., Ragu-Nathan, B., Ragu-Nathan, T. and Subba Rao, S. (2006). The impact of supply chain management practices on competitive advantage and organizational performance, Omega, 34 (2), pp. 107-24.

Lummus, R.R. and Vokurka, R. J. (1999). Defining supply chain management: a historical perspective and practical guidelines, Industrial Management \& Data Systems, 99 (1), pp. 11-17.

Manzouri, M., Rahman, M. N. Ab., Arshad, H., and Ghani, J. A. (2011). Cutting Down the Difficulty of SCM Implementation: a Comparison between Iranian and Malaysian Companies, Applied Mechanics and Materials, 44-47, pp.3652-3656.

Meehan, J., Muir, L. (2008). SCM in Merseyside SMEs: benefits and barriers, The TQM Journal, 20(3), pp. 223232.

Miguel, P. L. S., Ledur Brito, L. A. L. (2011). Supply Chain Management measurement and its influence on Operational Performance, Journal of Operations and Supply Chain Management, 4 (2), pp. 56 - 70.

Petrovic-Lazarevic, S., Sohal, A. and Baihaqi, I. (2007). Supply chain management performance the Australian manufacturing industry, available at: www.buseco.monash.edu.au/mgt/ research/working papers/2007/wp21-07.pdf (accessed 7June 2011).

Ramesh, A., Banwet, D. K. and Shankar, R. (2010). Modeling the barriers of supply chain collaboration, Journal of Modelling in Management,5( 2), pp. 176193.

Silk, A., and Kalwani, M. U. (1982). Measuring influence in organizational purchase decisions, Journal of Marketing Research, 19, pp.165-81.

Soni, G., and Kodali, R. (2011). A critical analysis of supply chain management content in empirical research, 
Business Process Management Journal, 17(2), pp. 238-266.

Spens, K., and Wisner, J. (2009). A Study of Supply Chain Management Practices in Finland and the United States, Operations and Supply Chain Management: An International Journal, 2(2), pp. 79-92.

Stock, J.R. and Boyer, S.L. (2009). Developing a consensus definition of supply chain management: a qualitative study, International Journal of Physical Distribution \& Logistics Management, 39 (8), pp. 690-711.

Thongrattana, P. T., and Perera, N. (2010). Perceived Environmental Uncertainty along the Thai Rice Supply Chain: An Empirical Approach, Operations and Supply Chain Management: An International Journal, 3(3), pp. 117-133.

Valmohammadi, Ch.(2011a). Investigating Mass Customization Implementation in Iranian
Manufacturing Organizations, Applied Mechanics and Materials, 87, pp.159-163.

Valmohammadi, Ch.(2011b). The impact of TQM implementation on the organizational performance of Iranian manufacturing SMEs, The TQM Journal, 23(5), pp.496-509.

Valmohammadi, Ch.(2012). Investigating the perceptions of Iranian employees on teleworking, Industrial and Commercial Training, 44(4), pp.236-241.

Wong, C.Y., Arlbjorn, J. S. and Johansen, J. (2005). Supply chain management practices in toy supply chain, Supply Chain Management: An International Journal, 10(5), pp. 367-78.

Zailani, S., Premkumar, R., and Fernando, Y. (2008). Factors Influencing the Effectiveness of Operational Information Sharing within Supply Chain Channels in Malaysia, Operations and Supply Chain Management: An International Journal, 1(2), pp. 85-100.

Dr. Changiz Valmohammadi is an assistant professor at Islamic Azad University-South Tehran Branch, Department of Industrial Management. His areas of interest are quality and productivity management, strategic management, project management, operations management, SCM, etc. For about 15 years he has taught undergraduate, graduate and industry courses and carried out research in various aspects of industrial engineering and management. His research papers have been published in journals such as The TQM Journal, International Journal of Productivity and Performance, Innovation: Management, Policy \& Practice, Business Strategy Series, Journal of Industrial Engineering International, etc. He is a senior member of American Society for Quality (ASQ). 